\title{
$17 \mathrm{Cr}-4 \mathrm{Ni}-4 \mathrm{Cu}$ 型不銹鋼冷間圧延材の諸性質に 及ぼす C の影響㫫びに含窒素鋼への $\mathrm{Cu}$ の影響
}

\author{
田中良平** 佐藤昭**
}

Ryồhei Tanaka and Akira Satô: Effect of $\mathrm{C}$ on the Properties of the Cold-Rolled $17 \mathrm{Cr}-4 \mathrm{Ni}-4 \mathrm{Cu}$ Type Stainless Steels and of $\mathrm{Cu}$ on Those of the ColdRolled Steels Containing N. (Study on $17 \mathrm{Cr}-4 \mathrm{Ni}-4 \mathrm{Cu}$ Type Stainless Steels ( $3 \mathrm{rd}$ Report)). In order to give $17 \mathrm{Cr}-4 \mathrm{Ni}-4 \mathrm{Cu}$ type stainless steels both strength and corrosion resistance by cold-rolling and age-hardening, the authors studied the effect of $\mathrm{C}$ addition up to $0.10 \%$ on the properties of the steels and the effect of $\mathrm{Cu}$ content up to $6 \%$ to the steels containing $0.17 \% \mathrm{~N}$ using dilatometric, hardness and metallographic examinations and corrosion tests. With increase of $\mathrm{C}$ and $\mathrm{Cu}$ contents the $\mathrm{Ms}$ temperature was lowered, the amount of the retained austenite was increased and the aging characteristics was enhanced. The effect on the aging characteristics was significant, particularly in the cold-rolled state. It was concluded that the addition of about $4 \%$ of $\mathrm{Cu}$ to the steel containing $0.17 \% \mathrm{~N}$ gives the best results after cold rolling followed by the aging treatment at about $440^{\circ} \mathrm{C}$, and that the addition of $\mathrm{C}$ deteriorates remarkably the antisulphuric acid property, though this increases the hardness of the steel after rolling and aging.

(Received November 10, 1958)

\section{I. 緒言}

第 2 報 (1) では冷間圧延と時効処理による諸性質の変化 に及ぼす $\mathrm{Ni}, \mathrm{Cu}$ 扎よび $\mathrm{N}$ の影響について研究し, 17 $\% \mathrm{Cr}-4 \% \mathrm{Ni}-4 \% \mathrm{Cu}-0.17 \% \mathrm{~N}$ の組成が最もすぐれた性 質を示すことを報告したが，本報ではさらに $17 \mathrm{Cr}-4 \mathrm{Ni}$ -

** 東京工業大学金属岡本研究室

* 1958 年 10 月本会名古屋大会に発表； $17 \mathrm{Cr}-4 \mathrm{Ni}-4 \mathrm{Cu}$ 型不銹鋼に関寸る研究(第3報)

(1) 岡本, 由中, 佐藤：本誌, 22(1958),504.
$4 \mathrm{Cu}$ の基準組成についてCの影響をしらべ，また $0.17 \%$ の $\mathrm{N}$ と 0〜6\%の $\mathrm{Cu}$ とを同時添加した場合の影響を $0 \sim 6 \% \mathrm{Cu}$ の単独添加の場合と比較した.

\section{II. 試料及び実験方法}

$\mathrm{Cr} 17 \%-\mathrm{Ni} 4 \%-\mathrm{Cu} 4 \%$ に一定してCを 0.05 及び $0.10 \%$ 添加した C Series(記号 C 05,C10)及び Cr 17\%-Ni 4\%N $0.17 \%$ に一定してCuを0〜6\% の範井で $2 \%$ おき変 えた Cu-N Series (記号 Cu 0 N 17〜Cu 6 N 17)の各試料 
を潌製した。それらの記号,配合組成, 熔解原料及び熔製方 法についてはすでル第 1 報(2)心述べてあり，また鋳造後の 印延及び焼鈍については第 2 報に記したところと全く同様 であるからここには省略する.な招上記試料中 Cu 6 N 17 のみは熱閒及び冷間の王延加工に際し, 割れが入り易く, 硬 度及び腐蝕試験用の小試片を辛うじて作製し得た程度であ るが,その他の試料の加工にはなんら支障を認めなからた。

\section{III. 実験結果とその考察}

\section{Ac 点及びMs 点に及ぼす $\mathrm{Cu}+\mathrm{N}$ 及び $\mathrm{C}$ の影響}

各試料の $1000^{\circ} 15 \mathrm{~min}$ 加熱水冷の溶体化焼入 試 料を $1000^{\circ}$ ま $10^{\circ} \mathrm{C} / \mathrm{min}$ で加熱, $15 \mathrm{~min}$ 保持後空冷した場 合の全脰脹曲線を測定し，これらの曲線からそれぞれの加 熱变態点 $\mathrm{Ac}$ 及び $\mathrm{Ms}$ 点を求め, $\mathrm{Cu} \%$ 及び $\mathrm{C} \%$ に対し て Fig.1 に図示した. Ac 点は $\mathrm{Cu}+\mathrm{N}$ 及び $\mathrm{C}$ の添加量

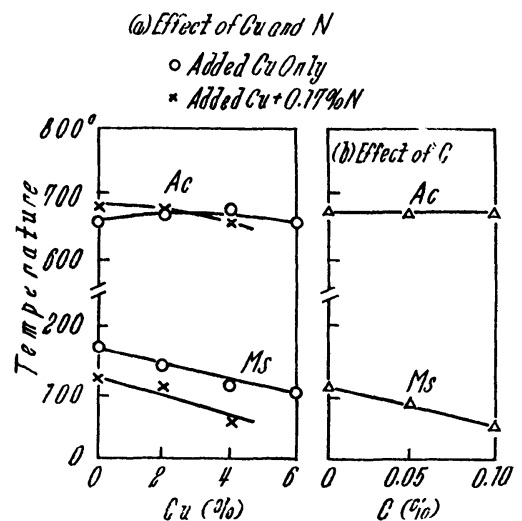
content on Ac and Ms temperature.
Fig. 1 Effect of $\mathrm{Cu}, \mathrm{N}$ and $\mathrm{C}$

によつてほと んど変化して いない.しか 乙 Ms 点は $\mathrm{Cu}$ を単独添 加した場合に 較べて $\mathrm{Cu}+$ $0.17 \% \mathrm{~N}$ の 添加では約 40 $\sim 50^{\circ}$ 低く現 われ, かつ やはり $\mathrm{Cu}$ の 増すほど Ms 点は低下す る. 一方 C も著しく Ms を下げ $0.1 \%$ の添加で約 $60^{\circ}$ 降下する. 第 2 報で $0.1 \%$ の $\mathrm{N}$ の添加により約 $38^{\circ} \mathrm{Ms}$ 点が降下することを報告したが，CのＭs点に及ぼす影 響は $\mathrm{N}$ よりもかなり著しいことがわかる。

\section{2. 飽和磁気による残留オーステナイト 垔の測定}

前報と同様 $\mathrm{CuO}$ の $30 \%$ 冷間圧延試料の組織を 100\% マルテンサイトとし, 溶体化焼入並びに $30 \%$ 冷間圧延の 各試料の磁気の強さを磁力計によつて測定し, それぞれの 残留オーステナイト量を求めた. Fig.2 はその測定結果を 示し, $\mathrm{Cu}$ の単独添加の場合には $\mathrm{Cu}$ 量の増加に伴つてあ まり残留オーステナイト量は增加しないが, $\mathrm{N}$ を共存せし めると著しくその量を增し，例えば $4 \% \mathrm{Cu}$ 単独添加の場 合の残留オーステナイト量約 $10 \%$ に較べ， $4 \% \mathrm{Cu}+0.17 \%$ $\mathrm{N}$ では 70\% にも增加する. 一方 C の添加も著しく残留 オーステナイト量を増加し， $0.1 \%$ 添加でその量は 65 \%となつている.これは丁度 N $0.17 \%$ 添加した場合に匹 敵し，Cは $\mathrm{N}$ よりあさらに強くオーステナイトを残留せ しめる作用をるつことがわかる．しかしいずれの試料も図

(2) 岡本, 岡田: 本誌, 22(1958),363.
に示すように冷間圧延によつて残留オーステナイトのかな りの部分が容易にマルテン化するのである.

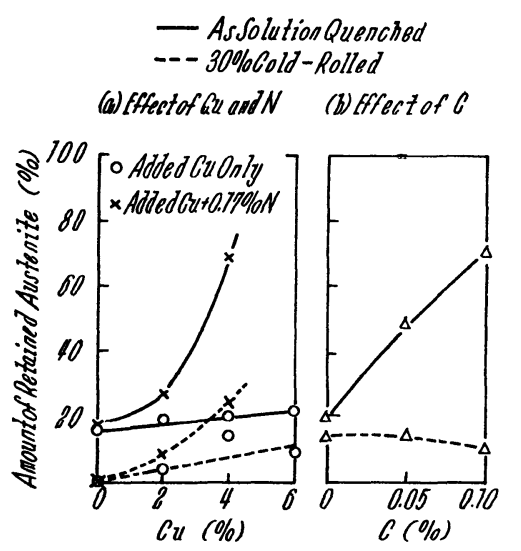

\section{3. 焼戻示 差 膨脤 測 定}

$\mathrm{Cu}+\mathrm{N}$ 及び $\mathrm{C}$ 添加による空 化物, 炭化物の 析出並びに $\mathrm{Cu}$ rich 相の 析出 現象やそれに伴 32 次マルテン 化を観察するた め，第 2 報と同

Fig.2 Effect of $\mathrm{Cu}, \mathrm{N}$ and $\mathrm{C}$ content on the retained austenite of alloys in the state of $1000^{\circ}-15 \mathrm{~min}$ water quenching.

様純鉄を中性体 として各試料の 溶体化状態と冷 間圧延状態とに ついて $540^{\circ}$ ま加熱, $3 \mathrm{hr}$ 保持空冷の示差膨脹曲線を求 めた。 そのうち C 10 の测定曲線を Fig.3 に示す. 同図

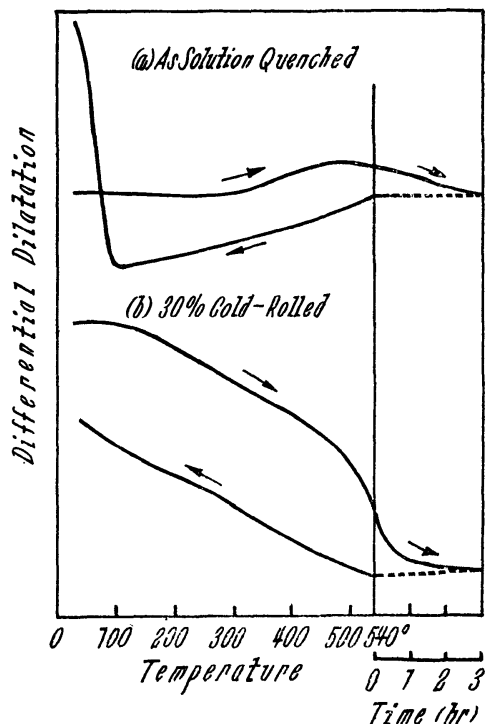

Fig.3 Differential dilatation curves of the alloy C10. (a) は溶体化 処理状態のもの であつて, 残留 オーステナイト が多い曲線は概 して右上りの傾 向を示している が, $100^{\circ}$ から $300^{\circ}$ 附近までと $500^{\circ}$ 以上との 2 段の収縮を示し ている.これら はマルテンサイ トの分解による ものであり，と くに500以上で は炭化物ととす に Cu に富む相
の析出が起るものと考えられる. しかして $540^{\circ} 3 \mathrm{hr}$ 加熱 中の収縮量はあまり多くはないがこれを冷却すると $100^{\circ}$ 附近より異常な膨脹が認められる。これは先の炭化物など の析出によつて残留オーステナイトが不安定となり, 冷却 中に 2 次マルテン化が起ることを示すむのである. 前報で Nを含む残留オーステナイトは熱的にはかなり安定で容易 に 2 次マルテン化しないことを強調したが，C の添加はN 以上にオーステナイトを残留し易くするけれども, 焼戻せ ば容易に 2 次マルテンサイトに変態するのである.一方溶 体化試料を冷間圧延したものは Fig.2 からも明らかなよ らに, 残留オーステナイトがほとんどマルテン化している 
ため Fig.3(b) の加熱曲線は右下りとなり $500^{\circ}$ 以上での 析出が非常に促進され, 冷却曲線にはなんらの異常膨脹を も示さない。

\section{4.溶体化硬度及び冷間圧延硬度}

$1000^{\circ} 15 \mathrm{~min}$ 加熱水冷の溶体化硬度並びに $30 \%$ 冷間圧 延硬度と添加元素量との関係を Fig.4 に示す. Cu の単独

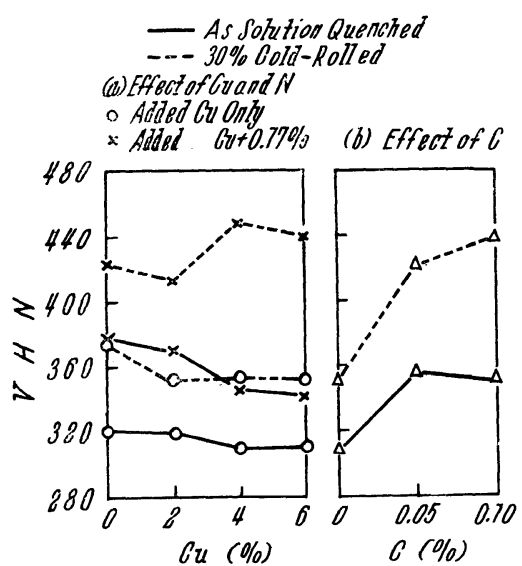

Fig.4 Effect of $\mathrm{Cu}, \mathrm{N}$ and $\mathrm{C}$ content on hardness of the alloys in both solution-quenched and subsequently $30 \%$ coldrolled states.

添加では硬度 は著しい変化 を示さない が，Nを同時 に加えた場合 は同一 $\mathrm{Cu}$ 量 の合金に較べ $\tau \mathrm{Hv}$ 約 30 ６0高い硬度 を示し，かつ $\mathrm{Cu}$ 量の增加 に伴い硬度は やや低下して いる.これは $\mathrm{N}$ の固溶によ つて素地, と くにマルテンサイトの硬度を著しく高める反面, 前述のよ うに残留オーステナイト量の增加も著しいためである，C も $\mathrm{N}$ 同様にマルテンサイトの硬度を高める反面, 残留オ 一ステナイト量を著しく増すことは前述の通りで，そのた め Fig.4(b)のように $0.05 \%$ の添加ではかなり硬度を增 すが $0.10 \% \mathrm{C}$ ではかえつて硬度は低下する．同図の $30 \%$ 常温圧延硬度は溶体化状態に比してかなり硬度を増加して いるが，とくに $\mathrm{N}$ や C を含も合金，すなわち残留才ース テナイトの多いもの淘ぞ冷間圧延によるそのマルテン化の ために硬度增加が著しい。

Fig.5 は $60 \%$ までの冷間圧延による各試料の硬度变化

(a) Effect of Cu

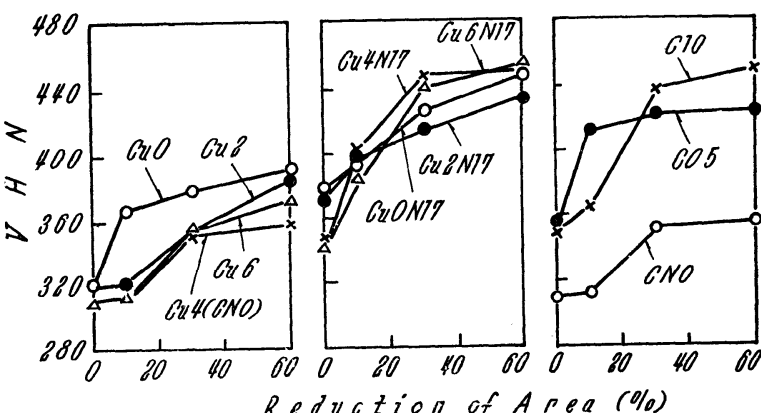

Fig.5 Hardness change by cold-rolling of alloys after $1000^{\circ}-15 \mathrm{~min}$ water quenching.

を示す. 同図 (a)において $\mathrm{Cu}$ 単独添加試料はいずれも溶 体化のま〉で相当量のマルテンサイトを含むため, 圧延前 ですでに Hv 300 以上のかなり高い硬度をもち，冷間圧延

による加工硬化は僅かである。一方 $\mathrm{Cu}+\mathrm{N}$ 添加のものは 残留オーステナイト量が多くなり，かつ冷間圧延によつて これが $\mathrm{N}$ を含むマルテンサイトに変態し，これが加工硬

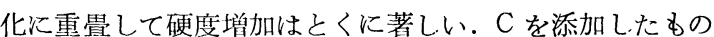
も王延による硬化が著しく、これは C を含むマルテンサイ トの生成によるものとして同様に説明される.

\section{5. 時効硬化 性}

各試料の溶体化のま〉及び $30 \%$ 冷間圧延試片の 400〜 $540^{\circ}$ での時効硬度变化を測定した．Fig.6はとの5ち $\mathrm{Cu}$

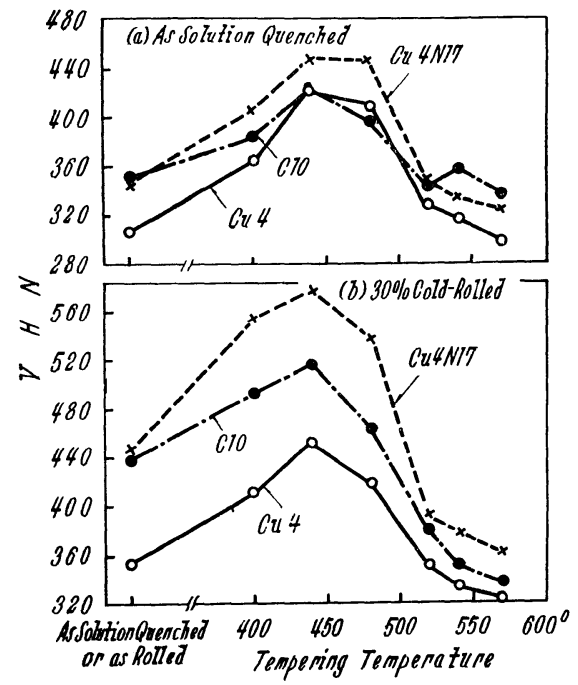

Fig. 6 Hardness change of the alloys due to aging for $3 \mathrm{hr}$ at each temperature after the solution-quenching or after the subsequent cold-rolling.
$4, \mathrm{Cu} 4 \mathrm{~N}$ 17 及び C 10てつ いて各温 度に $3 \mathrm{hr}$ 保持した ものの硬 度を時効 温度に対 乙て図示 したもの でいずれ も顕著な 焼戻硬化 を示し， cくに圧 延試料に その倾向 が著しい が,440附近で硬度は最高となり,それ以上の温度では却つ て急激に軟化している. しかしC 10の溶体化処理試料だけ は Fig.3(a) の2 次マルテン化に対応して $540^{\circ}$ で僅かに 硬度の增加が認められるが，この硬度增加は $440^{\circ}$ 附近の 顕著な硬化に比較すれば微々たるものである。このよ5に 時効硬化の最も顕著に起る゙のは $440^{\circ}$ 附近であつて 2 次マ ルテン化はさらに $100^{\circ}$ も高い温度で尭戾さなければ認め られず，それによる硬度增加は僅少であり，かつ後述する ように耐蝕性の著しい劣化を伴うため実用的にはきとんど 問題とはならない。な沶示差膨脹曲線に打ける $\mathrm{Cu}$ に富ん だ相などの析出と凝集とは約 $500^{\circ}$ 以上に現われるが，前述 のように焼戻硬度はそれより低い $440^{\circ}$ 附近で最高となり， またこの温度では後述するように耐蝕性はほとんど劣化し ないことから硬化は $\mathrm{Cu}$ に富む相の析出前の準備過程に。 ける格子歪に基因するものと思われ，完全に析出が行われ て明瞭な収縮が認められるころはすでにかなり軟化するの である。

次に最も時効処理に適当と思われる $440^{\circ}$ に $1 / 3 \sim 27 \mathrm{hr}$ 焼戻した場合の各試料の時効硬化曲線を Fig.7 に示す. 各試料とも3〜9 hr で最高硬度に達しそれ以上では軟化を 示す. しかに, C 05, C 10 は $27 \mathrm{hr}$ でもな抔度は增加し ている.これは残留オーステナイトが多いため第 $1 ， 2$ 報 
で述べたように析出が遅滞されることによるものである。 $\mathrm{Cu}$ の単独添加の場合には $\mathrm{Cu}$ の多い注ど時効硬化が顕著

\section{- As Solution Quenched \\ --- $30 \%$ Cold Rolled}

$\begin{array}{lll}\text { (a) Effect of Cu } & \text { (b) fffect of Gut0.19\%N } & \text { (c) Effect of } C\end{array}$

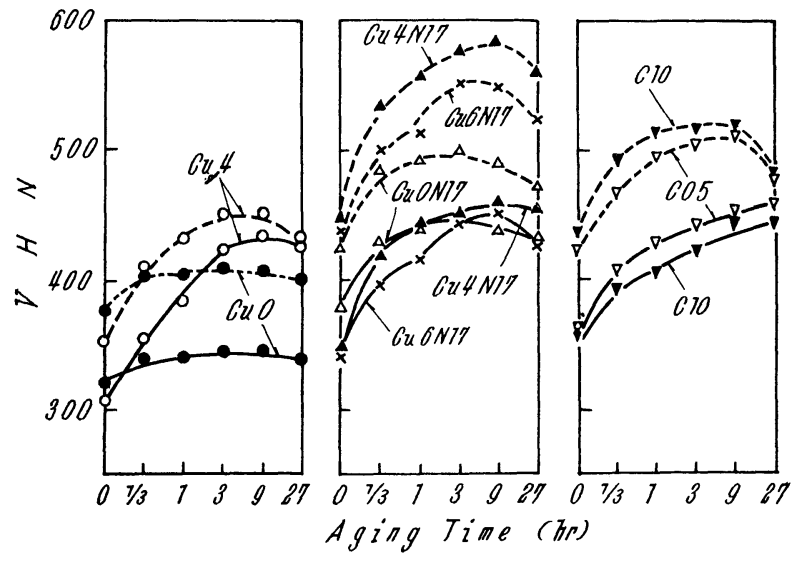

Fig.7 Age-hardening curves at $440^{\circ}$ of alloys after the water quenching and after the cold-rolling.

であるが， $\mathrm{Cu}+\mathrm{N}$ 添加をしたものは $4 \% \mathrm{Cu}$ で最も硬化 が著しく， $6 \% \mathrm{Cu}$ では溶体化試料，王延試料ともに却 つて時効硬度は低下する．Cの添加に扣いても溶体化試料 の時効硬度は C 05 で最高となり，C 10 では却つて硬度を 低下する.しかし冷間圧延すると C 10 でもほとんどマル テンサイトのみとなつて析出が容易となり時効硬度はC 05 より高くなる。

\section{6. 腐蝕試験結果}

溶体化試料及び30\%冷間世延試料を 400 ～540 の各温度 にそれぞれ $3 \mathrm{hr}$ づつ加熱時効させて後空冷し，5\% 沸騰

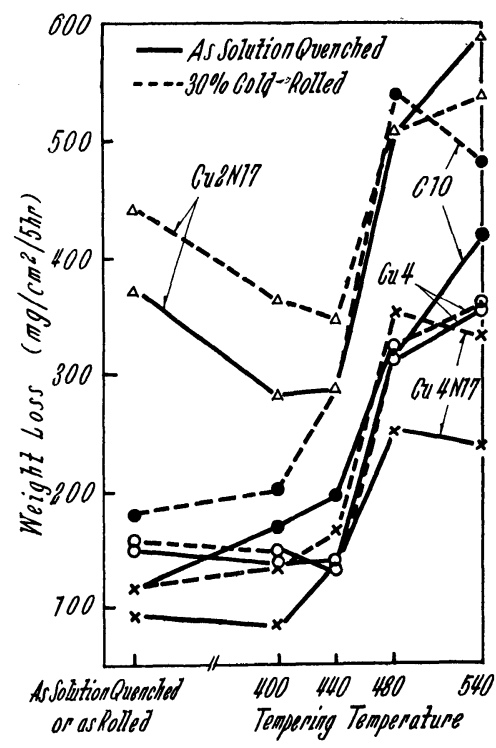

Fig. 8 Effect of tempering temperature on corrosion in $5 \%$ boiling sulphuric acid $5 \mathrm{hr}$ test.
うに本系合金の特色である。しかしながら含C 合金では戍 のC 10 の州線から明らかなよ $5 に 400^{\circ}$ 扣よび $440^{\circ}$ の焼戾 でもすでにかなり腐蝕量を增加しており，前報の 17-7 及 び 18-8 鋼の実験結果とその做向がよく類似している.す なわらこれらの不銹錪中の C は焼戻によつて炭化物とし て容易に析出し，機械的性質は向上するが，440。娔戻によ つてさえも著しく酎蝕性を害するものと考えられる．480 以上になるといずれの試料す急激に腐蝕減量を增し, とく に C を含むもの及び $\mathrm{Cu}$ 量の少いものは著しい腐蝕量を 示す. Fig.9 は $440^{\circ} 3 \mathrm{hr}$ 時效試料の耐硫酸性に及ぼす添

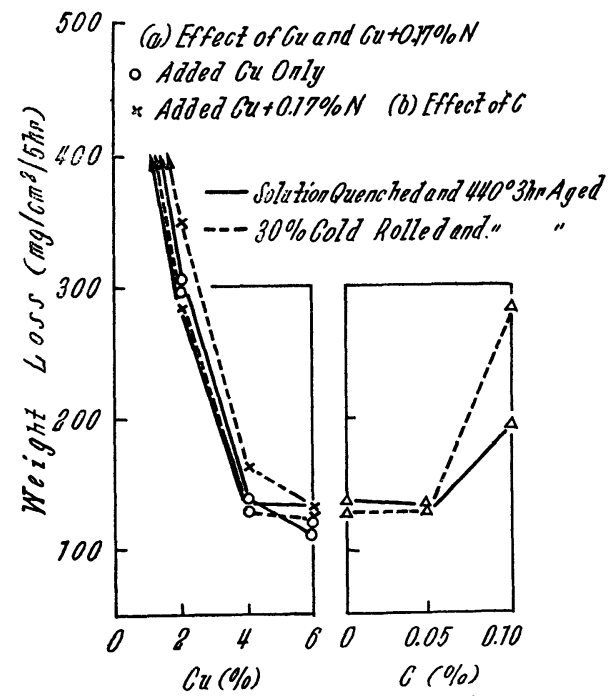

Fig.9 Effect of $\mathrm{Cu}, \mathrm{N}$ and $\mathrm{C}$ on corrosion in $5 \%$ sulphuric acid $5 \mathrm{hr}$ test.

加元素の影響を見たものである. Cu の影響はN 添加の有 無厄かかわらず極めて顕著であり，4\%まで著しく耐硫酸 性を改善する.Cは $0.05 \%$ の添加ではあまり影響しない が， $0.1 \%$ の添加で著しく耐硫酸性を害する.

次に $63 \%$ 沸騰硝酸による腐蝕を見るに，いずれの試料 も圧延及び $440^{\circ}$ まで焼戻してもその腐蝕量は硫酸の場合 に較べてごく僅かであり, $50 \mathrm{hr}$ の腐蝕試験で高々 20〜 $30 \mathrm{mg} / \mathrm{cm}^{2}$ に過ぎず,この系の合金の耐硝酸性は概ね良好 であることを示している．ただしＣ10 のみは $30 \%$ 正延 $440^{\circ} 3 \mathrm{hr}$ 焼戾で約 $50 \mathrm{mg} / \mathrm{cm}^{2}$ の腐蝕減量を示し, C の 添加は耐硝酸性の上でも好ましくないことがわかる.

さて強度と耐蝕性という観点から各鋼の優劣を比較する ために $5 \%$ 硫酸による $5 \mathrm{hr}$ の腐蝕減量を縦軸に，またそ れぞれの試料の硬度を横軸にとつて各試料の烧戻温度（各 温度 $3 \mathrm{hr}$ 加熱）に上る硬度及び腐蝕減量の関係曲線を求 めた．Fig.10にはその中 $\mathrm{CN} 0, \mathrm{Cu} 4 \mathrm{~N} \mathrm{17,Cu} 6$ N 17 及び C 10 の各冷間压延試料の結果のみを示した. 図から明らか なように CN0に較べて Cu 4 N 17, Cu 6N 17 とも耐蝕性 の点では同程度であつて遜色なく, とくに Cu 4 N17 は硬 度に和いて最も優れている. C 10 は硬度は CN0よりる 
高くなつているが，Cu4 N17に較べるとな拓硬度低く，

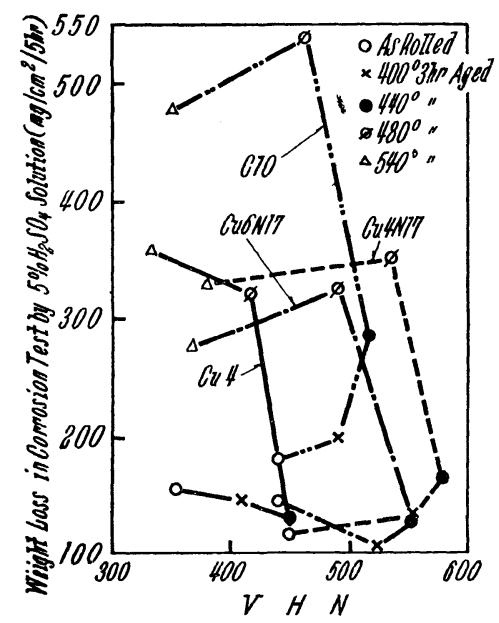

Fig.10 Relation between the corrosion in $5 \%$ boiling sulphuric acid 5 hr test and the hardness of the alloys coldrolled by $30 \%$ and subsequently aged for $3 \mathrm{hr}$ at each tem perature.

\section{IV. 結 論}

$17 \% \mathrm{Cr}-4 \% \mathrm{Ni}-4 \% \mathrm{Cu}$ 型不銹鋼の鍛鍊材について冷間 圧延と時効処理に上る諸性質に及ぼす $0.10 \%$ までのCの 影響並びに $0.17 \%$ の $\mathrm{N}$ と 0 6\% の $\mathrm{Cu}$ とをともに添 加した場合の影響についてしらべた。その結果を要約すれ

さらに耐蝕性
ば,

(1) $\mathrm{Cu}+\mathrm{N}$ の添加は同量の $\mathrm{Cu}$ を単独で加えた場合よ り Ms 点を約 40 〜 $50^{\circ}$ 下げ残留オーステナイト量を著しく 增加する．Cの添加によつても Ms 点はかなり降下し残留 オーステナイトを増すが，冷間压延によつてそれら残留才 ーステナイトの大部分はマルテン化する.

(2) C を含む残留オーステナイトは $540^{\circ}$ 以上に燃戻し て冷却すると 2 次マルテンサイトに変態するが，それによ る硬化は僅少で耐蝕性の点からもこのような温度での焼戾 は無意味である。

（3） $0.17 \% \mathrm{~N}$ と 0 6\% Cu とをともに添加する場合は $4 \% \mathrm{Cu}$ で時効硬化性が最も大となる。また含 C 合金も圧 延及び時効によつて著しい硬化を示す。

（4）本系合金怜間圧延及び $440^{\circ}$ までの焼戻によつて ほとんぞ耐蝕性が劣化しないという特徵が認められたが, Cの添加は耐硫酸性を著しく害しとくに $440^{\circ}$ までの焼杘 しによつてさえかなり耐蝕性が劣化する．Nはほとんぞ耐 蝕性に影響を与えない，耐硝酸性は概して良好であるが， 含 C 合金のみや小腐蝕量が增加する。

(5) 以上の結果よりこの系の合金に対してはC の添加は 好ましくなく, $\mathrm{Cu} 4 \%$ と N 0.17\% の同時添加で最も優 れた性質を示すことが結論される。

終りに臨み，終始御懇篤なる御指導を賜わりました恩師 岡本正三先生に深く感謝の意を表します。 また実験に協力 されました広瀬文夫君に厚く㧍礼申し上げます。 